\title{
Logistyka zwrotów a podejście procesowe - zależności i etapy tworzenia
}

Dr Katarzyna Huk

Uniwersytet Zielonogórski, Katedra Logistyki i Systemów Informacyjnych

\section{Wprowadzenie}

Nieustanny rozwój nowych technologii, globalizacja, wirtualizacja to tylko niektóre czynniki wpływające na zmiany w gospodarce. Jednym z elementów, który bezpośrednio oddziałuje na logistykę, jest rozwój e-commerce. Obecnie klient jest świadomy swoich decyzji i możliwości, jego wymagania stale rosną, stąd konieczność rozwoju nowego rynku sprzedaży. Handel przez internet staje się coraz bardziej popularny i choć zwroty produktów dotyczą wszystkich branż i kanałów sprzedaży, to w e-commerce widać ich największy wpływ na procesy sprzedaży i dystrybucji. Ich liczba stale rośnie, a prace związane z ich ponownym wdrożeniem w cykl sprzedaży są dość skomplikowane i wymagają zdefiniowanych działań. Jednym z rozwiązań usprawniających logistykę zwrotów jest podejście procesowe, a dokładniej tworzenie map procesów. Wykorzystanie podejścia procesowego daje organizacji wiele możliwości: szybszy przepływ produktów, określenie możliwości działań związanych ze zwracanym towarem, szybsze wdrożenie pracowników, instrukcje i procedury dotyczące samego procesu, informacje o odpowiedzialności za poszczególne zadania itd. Celem artykułu jest wskazanie zależności i etapów tworzenia procesu mapowania w logistyce zwrotów. Opracowanie ma charakter teoretyczno-empiryczny i zostało oparte na analizie literatury oraz przeprowadzonych studiach przypadku.

\section{Logistyka zwrotów a logistyka zwrotna - idea i charakterystyka}

Logistyka zwrotów identyfikowana jest bardzo często z szerszym pojęciem - logistyką zwrotną. Zakres pojęcia logistyki zwrotnej związany jest z istotą łańcucha dostaw i przepływów w nim zachodzących. Sam łańcuch dostaw, jak stwierdza Jarosław Witkowski, to „współdziałające w różnych obszarach funkcjonalnych firmy 
wydobywcze, produkcyjne, handlowe, usługowe oraz ich klienci, między którymi przepływają strumienie produktów, informacji i środków finansowych"1. Ponadto w literaturze przedmiotu zarządzanie łańcuchem jest definiowane także jako proces planowania, realizowania oraz kontrolowania sprawnego i efektywnego ekonomicznie przepływu surowców, materiałów, wyrobów gotowych oraz odpowiedniej informacji, z punktu pochodzenia do punktu konsumpcji, w celu zaspokojenia wymagań klienta ${ }^{2}$. Logistyka zwrotów związana jest z przepływami produktów w odwrotnym kierunku niż tradycyjny przepływ zachodzący w łańcuchach dostaw ${ }^{3}$. Będzie dotyczyć więc odwrotnych przepływów produktów, środków finansowych i informacji.

W literaturze przedmiotu nie ma jednoznacznych definicji określających procesy zachodzące w ramach logistyki zwrotnej. Można spotkać się z różnymi pojęciami, które jednak nie powinny być stosowane jako synonimy, na przykład „recykling”, „logistyka odpadów”, „odzysku”, „zwrotów”, „zwrotna”, „odwrotna” itd. Tak duża liczba pokrewnych pojęć spowodowana jest zmianami zachodzącymi w gospodarce, które powodują powstawanie nowych procesów lub wpływają na wzrost ich wagi. W ostatnich latach zauważa się wyraźne zwiększenie zainteresowania optymalizacją procesów produkcyjnych wspierających różne rodzaje procesów odzysku wartości produktów4 ${ }^{4}$. Jedną z definicji, która kładzie największy nacisk na odzysk produktów, jest ta zaproponowana przez Rogersa i Tibben-Lembkego: „proces wycofywania wyrobów z ich zwykłego miejsca ostatecznego przeznaczenia w celu przywrócenia im wartości albo pozbycia się ich we właściwy sposób"5. W szerszym ujęciu logistyka zwrotna to „ograniczanie ilości materiałów poprzez działania prowadzone w łańcuchu podaży w kierunku przeciwnym jego biegowi, w celu szerszego wykorzystania materiałów z odzysku i ich recyklingu oraz ograniczania całkowitej ilości zużywanych materiałów”6. Logistykę zwrotów,

1 J. Witkowski, Zarzq̨dzanie łańcuchem dostaw. Koncepcje, procedury, doświadczenia, Polskie Wydawnictwo Ekonomiczne, Warszawa 2010, s. 19.

2 J. Coyle, E. Bardi, C. Langley, Zarzq̨dzanie logistyczne, Polskie Wydawnictwo Ekonomiczne, Warszawa 2002.

3 K. Huk, J. Robaszkiewicz-Ostręga, Logistyka zwrotów na przykładzie hurtowni farmaceutycznej Neuca-Logistyca Sp. z o.o., „Prace Naukowe Uniwersytetu Ekonomicznego we Wrocławiu" 2018, nr 505, s. 304.

4 K. Witkowski, Aspekt logistyki zwrotów i recyklingu tworzyw sztucznych, [w:] J. Witkowski, A. Skowrońska (red.), Ekonomiczne, społeczne i środowiskowe uwarunkowania logistyki, „Prace Naukowe Uniwersytetu Ekonomicznego we Wrocławiu” 2015, nr 383, s. 303.

5 D.S. Rogers, R.S. Tibben-Lembke, Going backwards: Reverse Logistics Trends and Practices, Reverse Logistics Executive Council, Pittsburgh 2002.

6 C.R. Carter, L.M. Ellram, Reverse logistics: A review of literature and framework for future investigation, „Journal of Business Logistics” 2002, no. 9(1), s. 85. 
z uwagi na szerokie określenie tego pojęcia, będziemy uważać za „ogół procesów zarządzania przepływami odpadów (w tym produktów pełnowartościowych i uszkodzonych, ale uznanych przez ich dysponentów za odpady) i informacji (z tymi przepływami związanych), od miejsc ich powstawania (pojawiania się w systemie logistycznym) do miejsca ich przeznaczenia w celu ich ponownego użycia, odzyskania wartości (poprzez naprawę, recycling lub przetworzenie) lub właściwego składowania w taki sposób, by przepływy te były efektywne ekonomicznie i minimalizowały negatywny wpływ odpadów na środowisko naturalne człowieka"7. Głównym celem logistyki zwrotnej jest poszukiwanie prawidłowości dotyczących przepływów zwrotnych, biorąc za kryterium wyboru efektywność ekonomiczną i ekologiczną systemów logistyki zwrotnej ${ }^{8}$. Należałoby podkreślić tutaj także aspekt społeczny (klient dokonujący wyboru, np. na podstawie opinii i wizerunku firmy) czy też aspekt marketingowy. „Przedmiotem logistyki zwrotnej są przepływy odpadów (z zastrzeżeniem ich szerokiego rozumienia) oraz informa-

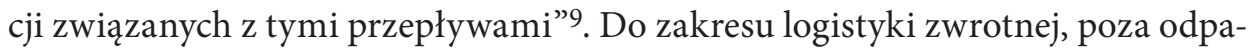
dami, należy włączyć również przepływy materiałowe związane z wycofywaniem z systemu logistycznego produktów pełnowartościowych oraz związanych z procesem napraw, reklamacji ${ }^{10}$. Jak wcześniej zauważono, zaliczyć tu można procesy związane z odzyskiwaniem wartości z produktów już wycofanych, a także obrót dobrami pełnowartościowymi. Z niniejszych rozważań wynika, iż do logistyki zwrotnej zaliczyć można: ponowne użycie produktów, ponowne wytworzenie, recykling, utylizację, zwroty produktów, reklamacje i serwis, gospodarkę opakowaniami. Przedmiotem zainteresowania niniejszego opracowania jest logistyka zwrotów produktów, która będzie wchodzić w zakres logistyki zwrotnej.

Pojawienie się nowych terminów, w tym także logistyki zwrotów, jest związane ze zmianami zachodzącymi w gospodarce. Zazwyczaj rozważania na temat łańcuchów dostaw skupiają się na przepływie od surowców do produktów gotowych. Zmiany preferencji klientów, ich rosnące wymagania oraz skracające się cykle życia produktów powodują nasilające się przepływy zwrotne produktów pełnowartościowych ${ }^{11}$. „Istotą współczesnego zarządzania łańcuchem dostaw jest proces decyzyjny związany z synchronizowaniem fizycznych, informacyjnych i finansowych strumieni popytu i podaży przepływających między jego uczestnikami w celu

7 J. Szottysek, Ewolucja logistyki zwrotnej, „Logistyka” 2009, nr 5, s. 85.

8 A. Sadowski, Logistyka zwrotna, [w:] S. Kauf, E. Płaczek, A. Sadowski, J. Szołtysek, S. Twaróg, Vademecum logistyki, Wydawnictwo Difin, Warszawa 2016, s. 183.

9 J. Szołtysek, Logistyka zwrotna, [w:] D. Kisperska-Moroń, S. Krzyżaniak (red.), Logistyka, Biblioteka Logistyka, Poznań 2009, s. 436.

10 Tamże, s. 436.

11 Tamże, s. 438. 
osiągnięcia przez nich przewagi konkurencyjnej i tworzenia wartości dodanej z korzyścią dla wszystkich jego ogniw, klientów oraz pozostałych interesariuszy"12.

Problemowy może wydać się wsteczny przepływ produktów w łańcuchach dostaw. Wiąże się to $\mathrm{z}$ wymaganiami klientów, wzrostem świadomości, ale także rosnącą konkurencją i przeniesieniem rynków w świat cyberprzestrzeni. E-commerce staje się coraz bardziej popularny, co wpływa także na procesy logistyczne zachodzące w przedsiębiorstwach. Obecnie klienci cenią sobie dostawę zintegrowaną, $\mathrm{z}$ wyznaczeniem przez dystrybutora konkretnej daty i dostarczeniem przesyłki w terminie ${ }^{13}$. Możliwość zwrotu towaru zakupionego poza siedzibą firmy, jaką daje nam polskie prawo, oddziałuje na przedsiębiorstwa i rozszerza ich obowiązki na konieczność przyjęcia zwracanego towaru. Przyczyn zwrotów jest wiele: od chęci sprawdzenia danego produktu po rozbieżności między stanem faktycznym a przedstawianym przez sprzedawcę. Ponadto na poziom zwrotów w łańcuchach dostaw wpływ mają: prognozowanie sprzedaży, projektowanie nowego produktu, promocja sprzedaży, polityka zakupów, produkcja, polityka zwrotów produktów od klienta ${ }^{14}$. Tylko dzięki dobrze opracowanemu planowi sprzedaży, jakości produktów i obsłudze klienta jesteśmy w stanie minimalizować koszty związane z logistyką zwrotów.

W zarządzaniu łańcuchem dostaw można wyróżnić cztery podstawowe kategorie operacji: planowanie, zaopatrzenie, wytwarzanie i dostarczanie ${ }^{15}$. Do tych operacji można zaliczyć jeszcze zwroty. Poprzez zwrot będziemy rozumieć oddanie zakupionego produktu przez klienta. Logistyka zwrotów będzie zatem dotyczyć procesów zwrotu produktu w głąb łańcucha dostaw. W zależności od danego przypadku może on dotyczyć detalisty, producenta, a nawet samego dostawcy surowca. Logistyka zwrotna będzie obejmować takie procesy jak: zwroty produktów (zakupionych np. przez internet), reklamacje i serwis, obieg opakowaniami, recykling i utylizację. Jest to wyjątek, jeżeli chodzi o przepływy strumieni w łańcuchach dostaw, ale z uwagi na nowe trendy sprzedaży i rozwoju rynku jest to bardzo strategiczny i szybko rozwijający się obszar logistyki.

12 J. Witkowski, Zarzq̨dzanie łańcuchem dostaw..., s. 36.

13 E.R. Slone, Leading a Supply Chain Turnaround, „Harvard Business Review” 2004, no. 10, S. $116-117$.

14 M. Bernon, J. Cullen, J. Gorst, Reverse logistics self assessment workbook, Department for Transport, Cranfield University, University of Sheffield, Sheffield 2008.

15 M. Hugos, Zarzq̨dzanie łańcuchem dostaw. Podstawy, One Press Exclusive, Gliwice 2011, s. 53. 


\section{Identyfikacja procesów logistycznych a podejście procesowe}

Problem terminologii w naukach o zarządzaniu jest dość duży z uwagi na różne znaczenie tych samych pojęć. Bardzo szerokim pojęciem okazuje się „proces”, ponieważ może mieć on inne interpretacje $z$ uwagi na zarządzanie procesowe, a inne $z$ uwagi na podejście do logistyki. Tezę tę potwierdza fakt, iż w ramach procesów logistycznych w praktyce tworzy się procesy. W literaturze przedmiotu czytamy, iż „proces można zdefiniować jako sekwencję lub częściowo uporządkowany zbiór powiązanych ze sobą działań, zintegrowanych przez czas, koszty, łączną ocenę wykonania i realizowanych, aby osiągnąć określony cel organizacji"16. Ponadto „proces będziemy nazywać logistycznym wówczas, gdy: rozmieszczenie, stan, przepływy jego składowych, a więc ludzi, dóbr materialnych, informacji i środków finansowych, wymagają koordynacji z innymi procesami ze względu na kryteria lokalizacji, czasu, kosztów i efektywności spełnienia porządnych celów organizacji”" Według Abta poprzez pojęcie „procesy logistyczne” powinno rozumieć się „procesy przepływu dóbr, polegające na fizycznym przemieszczaniu i magazynowaniu surowców, materiałów i produktów oraz na przepływie związanej z tym przemieszaniem informacji przez kolejne fazy różnego typu procesów gospodarczych, tak zorganizowane, aby realizacja tych procesów była sprawna i ekonomicznie uzasadniona"18. Tak więc proces logistyczny polega na fizycznym przemieszczaniu produktów przez kolejne fazy działalności gospodarczej, by w rezultacie zrealizować cel logistyki przewidziany na danym etapie dążenia do dostępności produktu na ustalonych zasadach i priorytetach ${ }^{19}$.

W działalności logistycznej można wyróżnić wiele procesów logistycznych. Należy też zwrócić uwagę, iż podziałów i klasyfikacji procesów w literaturze przedmiotu jest bardzo dużo. Jest to spowodowane przede wszystkim ciągłą ewaluacją logistyki i zmianami w gospodarce, które bezpośrednio oddziałują na działalność przedsiębiorstwa. Coyle, Bardi i Langley wyróżnili następujące procesy logistyczne ${ }^{20}$ :

- przemieszczanie i transport dóbr,

- magazynowanie i składowanie,

16 S. Krawczyk, Zarządzanie procesami logistycznymi, Polskie Wydawnictwo Ekonomiczne, Warszawa 2001, s. 34.

17 Tamże, s. 42.

18 S. Abt, Zarządzanie logistyczne w przedsiębiorstwie, Polskie Wydawnictwo Ekonomiczne, Warszawa 1998, s. 33.

19 S. Twaróg, System logistyczny, [w:] S. Kauf, E. Płaczek, A. Sadowski, J. Szołtysek, S. Twaróg, Vademecum logistyki, Wydawnictwo Difin, Warszawa 2016, s. 27.

20 J. Coyle, E. Bardi, C. Langley, Zarzq̨dzanie..., s. 69. 
- pakowanie przemysłowe,

- manipulacje materiałowe,

- kontrola zapasów,

- realizacja zamówień,

- prognozowanie popytu,

- planowanie produkcji,

- zakupy,

- obsługa klienta na odpowiednim poziomie,

- lokalizacja zakładów i magazynów,

- załatwianie zwrotów,

- dostarczenie części zamiennych i obsługa posprzedażna,

- gromadzenie i usuwanie odpadów.

Inne procesy logistyczne zostały wyodrębnione przez Twaroga (tabela 1). Autor dodatkowo wyróżnił działania logistyczne, które mieszczą się w kategoriach danych procesów.

Tabela 1. Procesy i czynności logistyczne

\begin{tabular}{|l|l|}
\hline \multicolumn{1}{|c|}{ Proces } & \multicolumn{1}{c|}{ Czynności } \\
\hline Transport & $\begin{array}{l}\text { Wybór rodzaju transportu i poziomu usług transportowych } \\
\text { Ustalenie sieci przewozów } \\
\text { Opracowanie harmonogramu ruchu pojazdów } \\
\text { Wybór konkretnego sprzętu transportowego } \\
\text { Załatwienie reklamacji } \\
\text { Kontrola stawek transportowych }\end{array}$ \\
\hline $\begin{array}{l}\text { Kształtowanie poziomu } \\
\text { i struktury zapasów }\end{array}$ & $\begin{array}{l}\text { Sformutowanie polityki zapasów surowców, materiatów i wyrobów } \\
\text { gotowych } \\
\text { Opracowanie krótkoterminowych prognoz sprzedaży } \\
\text { Określenie struktury zapasów w punktach magazynowania } \\
\text { Określenie liczby, rozmiarów i lokalizacji punktów magazynowania }\end{array}$ \\
\hline $\begin{array}{l}\text { Logistyczna obsługa } \\
\text { klienta }\end{array}$ & $\begin{array}{l}\text { Uzgodnienia zakresu potrzeb klientów i wymagań w stosunku } \\
\text { do systemu obstugi klientów } \\
\text { Przewidywanie reakcji klientów na ustalony system ich obstugi } \\
\text { Ustalenie ostatecznej jakości poziomu obsługi klienta }\end{array}$ \\
\hline Magazynowanie & $\begin{array}{l}\text { Określenie zapotrzebowania na przestrzeń magazynową } \\
\text { Projektowanie rozmieszczenia zapasów } \\
\text { Przyjmowanie, kompletacja i wydanie materiałów do i z magazynu }\end{array}$ \\
\hline $\begin{array}{l}\text { Wybór opakowań ułatwiających: } \\
\text { - operacje za-, wy- i przetadunkowe } \\
\text { - procesy magazynowania } \\
\text { - ochronę przed uszkodzeniami }\end{array}$ \\
\hline opakowanamiami
\end{tabular}

Źródło: S. Twaróg, System logistyczny, [w:] S. Kauf, E. Płaczek, A. Sadowski, J. Szołtysek, S. Twaróg, Vademecum logistyki, Wydawnictwo Difin, Warszawa 2016, s. 27. 
Z uwagi na różnorodność podejść do identyfikacji procesów logistycznych należy zwrócić uwagę, iż w głównej mierze będą one zależeć od rodzaju działalności przedsiębiorstwa, profilu, branży oraz rynków, w jakich ono działa. Można wyróżniać bardzo wiele procesów logistycznych, natomiast ich sposób interpretacji i realizacji zależeć będzie od specyfiki przedsiębiorstwa. Rojek podkreśla, iż procesy logistyczne „powinny prowadzić do tworzenia wartości dodanej dla klientów, a poprzez to przyczyniać się do realizacji wartości dodanej na rzecz przedsiębiorstwa"21. To spostrzeżenie pokazuje ideę i cel zarówno logistyki, jak i zarządzania logistycznego, a w końcu zarządzania łańcuchem dostaw. Tak więc realizacja procesów logistycznych będzie w głównej mierze mieć znaczenie przy wymienionych działaniach.

Podejście procesowe jest formą spojrzenia na organizację przedsiębiorstwa. W naukach o zarządzaniu mówimy o podejściu procesowym i systemowym. To pierwsze, jako zainteresowanie niniejszego opracowania, określa proces jako najważniejszy w organizacji, na który składa się ciąg czynności towarzyszących produkcji czy sprzedaży ${ }^{22}$. „Takie podejście do zarządzania nakazuje koncentrację uwagi na sekwencjach działań podejmowanych w organizacji i poza nią na powiązaniach między nimi w celu osiągnięcia zamierzonych wspólnie celów”23. Należy więc zwrócić szczególną uwagę na to, iż podejście procesowe będzie wyodrębniać główne procesy w organizacji, a one skutkować będą koniecznością realizacji różnych działań w celu osiągnięcia określonego rozwiązania. Podejście procesowe i procesy logistyczne stanowią odrębne kategorie. Podejście procesowe jest pojęciem szerszym. Identyfikując procesu logistyczne, w ich ramach możemy tworzyć poszczególne procesy i tak właśnie jest w przypadku logistyki zwrotów. Z uwagi na problemy i wielość działań związanych z logistyką zwrotów stosuje się właśnie podejście procesowe, w tym jako jedną z metod mapowanie procesów. Jest to niezwykle ważne, gdyż pomaga pracownikom i osobom zarządzającym na synchronizację działań i obrazowe określenie poszczególnych czynności, a także rozwiązań dotyczących zwracanych produktów, ich kontroli i dalszego zagospodarowania.

21 T. Rojek, Koncepcja tańcucha wartości w zarządzaniu przedsiębiorstwem, „Zeszyty Naukowe Uniwersytetu Szczecińskiego. Finanse, Rynki Finansowe, Ubezpieczenia” 2014, s. 815.

22 K.K. Bednarz, Podejście procesowe w komunikacji wewnętrznej przedsiębiorstwa, [w:] S. Nowosielski (red.), Podejście procesowe w organizacjach, „Prace Naukowe Uniwersytetu Ekonomicznego we Wrocławiu" 2009, nr 52, s. 29, [za:] K. Kondracki, Komunikacja w organizacjach, http://www.qpracy.pl (dostęp: 10.02.2020).

23 K.K. Bednarz, Podejście procesowe..., s. 29, [za:] S. Nowosielski, Procesy i projekty logistyczne, Wydawnictwo Uniwersytetu Ekonomicznego we Wrocławiu, Wrocław 2008, s. 40. 


\section{Podejście procesowe w logistyce zwrotów - mapowanie procesów}

Rozpatrując procesy zwrotów w przedsiębiorstwach, w pierwszej kolejności należy określić rodzaj produktów. W zależności od branży, w jakiej działają przedsiębiorstwa, powody zwracania produktów, a także możliwości ich dalszego obrotu będą się różnić. Z uwagi na branżę firmy wykorzystują różne możliwości dalszego zagospodarowania zwróconych produktów. I tak najczęstszymi formami zagospodarowania produktów pochodzących ze zwrotów w branży odzieżowej są: ponowne wprowadzenie produktów do sprzedaży, sprzedaż produktów na rynkach wtórnych, oddanie na cele charytatywne, zwrot produktów $z$ wadą fabryczną (jeżeli firma nie jest ich producentem), utylizacja lub recykling. W branży farmaceutycznej postępowanie w przypadku produktów pochodzących ze zwrotów jest dużo bardziej skomplikowane, gdyż leki muszą być segregowane według numeru partii. W związku z tym te pochodzące ze zwrotu trafiają do specjalnych stref przechowywania. Natomiast branża produktów elektronicznych ściśle weryfikuje oznaki użytkowania produktów i tutaj formy zagospodarowania tych towarów są następujące: zwrot do klienta, ponowna sprzedaż, wystawienie na wyprzedaże, oddanie produktów z wadą fabryczną. Różnice w procesach zwrotów produktów uzależnione są w głównej mierze od branży, w jakiej funkcjonują przedsiębiorstwa. Tak więc wydaje się, iż podejście procesowe i mapowanie procesów może stanowić doskonałe rozwiązanie dla skomplikowanych i różnorodnych działań w tym obszarze.

Uniwersalna dla wszystkich branż jest metodologia tworzenia tych procesów. Można tutaj wyróżnić uniwersalne kroki postępowania dla logistyki zwrotów, które należy podjąć w celu stworzeniach map procesów.

Etapy tworzenia map procesów dla zwrotów:

- stworzenie interdyscyplinarnego zespołu, składającego się z osób z różnych działów firmy, zaangażowanych przy zwrotach produktów,

- identyfikacja procesu, działań i obszarów funkcjonalnych,

- określenie przedmiotów zwrotu, asortymentu i działań z nim związanych,

- analiza systemu logistycznego przedsiębiorstwa,

- zebranie danych o realizowanych zwrotach, zamówieniach z ubiegłych okresów,

- analiza prognoz sprzedaży,

- określenie działań, działów i osób odpowiedzialnych za poszczególne etapy procesu zwrotu,

- próba stworzenia mapy procesu,

- konsultacja przygotowanej mapy z kadrą zarządzającą, 
- analiza mapy procesu z pracownikami bezpośrednio zaangażowanymi w zwroty produktów,

- modyfikacja mapy procesu,

- wdrożenie,

- monitorowanie i kontrola,

- wprowadzenie końcowych zmian,

- monitorowanie i ciągłe doskonalenie.

Etapy te pomogą przygotować mapę procesu dla zwrotu danego produktu. Natomiast istotne są również działania następujące po wdrożeniu danej mapy w struktury przedsiębiorstwa. Zmienne otoczenie przedsiębiorstwa, a także zmiany zachodzące wewnątrz organizacji danego podmiotu oddziałują na zmiany w procesach logistyki zwrotów. Na rysunku 1 przedstawiono schemat wdrażania i funkcjonowania map procesów dla logistyki zwrotów w przedsiębiorstwie.

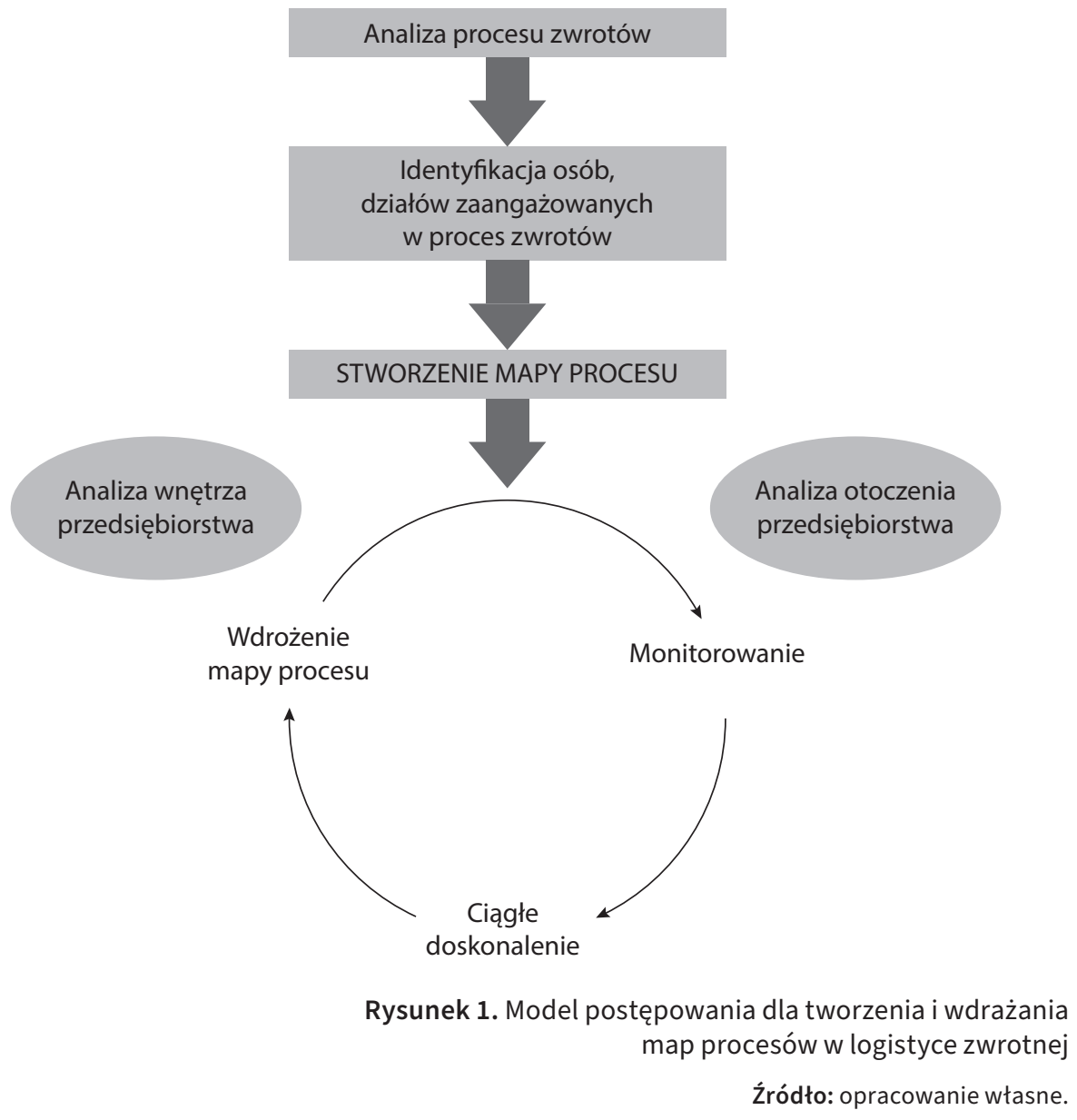




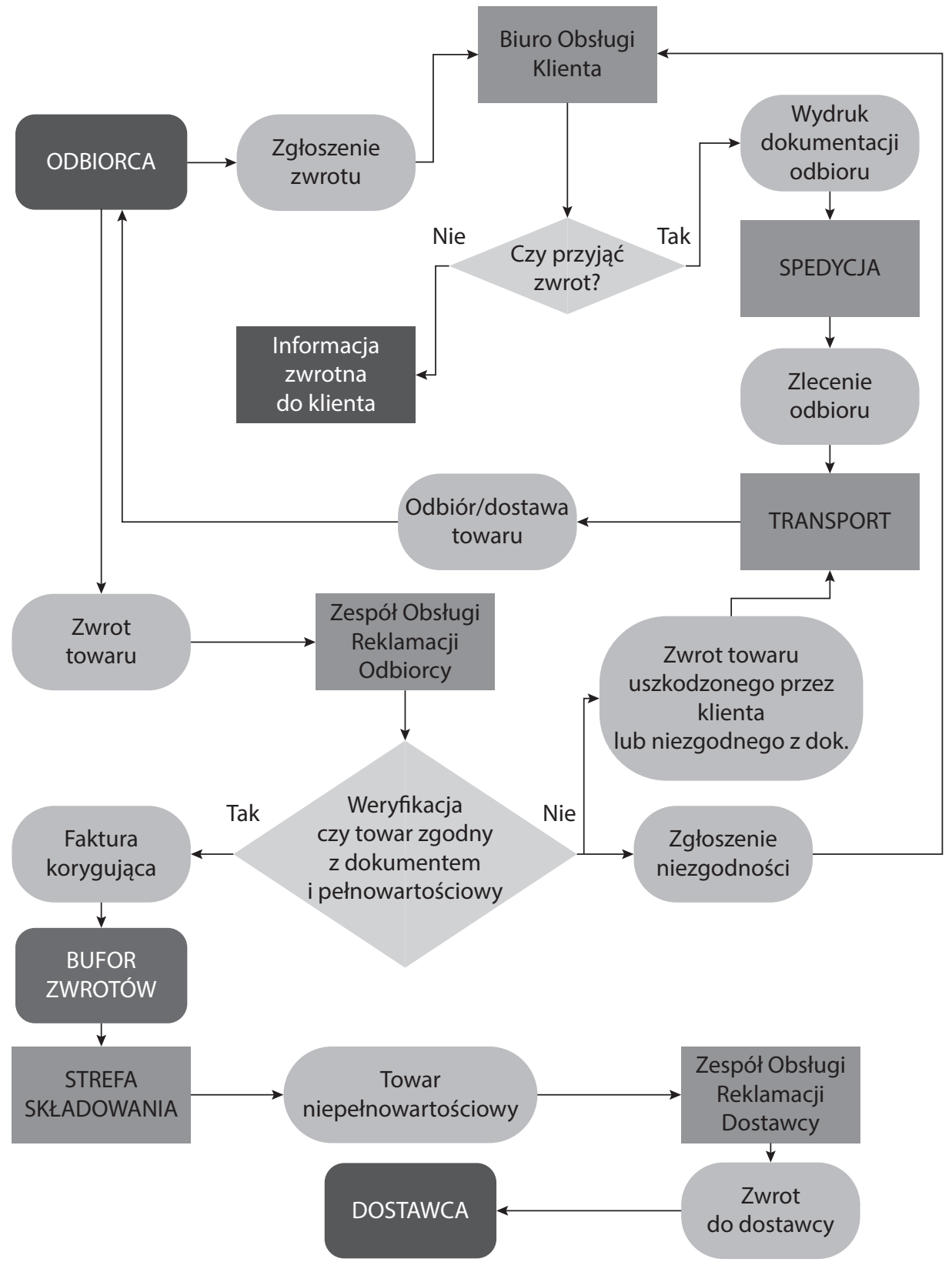

Rysunek 2. Schemat procesu reklamacji i zwrotów w Neuca-Logistyka Sp. z 0.o.

Źródło: K. Huk, J. Robaszkiewicz-Ostręga, Logistyka zwrotów na przykładzie hurtowni farmaceutycznej Neuca-Logistyca Sp. z o.o., „Prace Naukowe Uniwersytetu Ekonomicznego we Wrocławiu” 2018, nr 505, s. 312. 
Po dokonaniu analizy zwrotu towaru w danej organizacji należy zidentyfikować obszary funkcjonalne, których dotyczy ten proces, a także osoby będące interesariuszami danego procesu. Niezbędne wydaje się też sumienne przeanalizowanie otoczenia przedsiębiorstwa i jego wewnętrznych aspektów i możliwości. Samo wdrożenie map procesów i „nadanie im życia” w organizacji nie kończy działań. Procesy te powinny być systematycznie monitorowane, konsultowane i modyfikowane. Konieczne więc wydaje się ciągłe ich doskonalenie, wymuszane przede wszystkim przez zmienność otoczenia, a także elastyczne podejście do zmian i propozycji usprawnień.

Na podstawie wskazanych powyżej kroków postępowania można utworzyć mape procesu. Na rysunku 2 przedstawiono przykładowy schemat mapy procesu zwrotu produktów w hurtowni farmaceutycznej Neuca-Logistyka Sp. z o.o. Proces logistyki zwrotów w Grupie Neuca jest bardzo rozbudowany. Zwrot może nastąpić zarówno na linii odbiorca - hurtownia, jak i hurtownia - dostawca. W tym drugim przypadku mamy do czynienia głównie ze zwrotem do dostawcy produktów niepełnowartościowych, wycofanych z obrotu, wadliwie działającego sprzętu - pochodzącego zarówno ze zwrotów od odbiorców, jak i bezpośrednio ze strefy składowania, oraz towaru niezgodnego z dokumentacją dostawy i towaru niezamawianego. W Centrach Logistycznych Grupy Neuca reklamacjami i zwrotami do dostawców zajmują się pracownicy Zespołu Obsługi Reklamacji Dostawcy 24 .

Przedstawiony na rysunku 2 proces jest tylko wzorcem postępowania dla przedsiębiorstwa działającego w branży farmaceutycznej. Każda firma będzie charakteryzować się zmiennymi działania i specyfiką funkcjonowania, w związku z tym procesy powinny być identyfikowane i tworzone dla każdej organizacji indywidualnie.

\section{Zakończenie}

Procesy zachodzące w przedsiębiorstwie w znacznej mierze generują zmiany, jakie zachodzą na rynku. Preferencje klientów, sprzedaż nowymi kanałami, a także nowe formy i kanały dystrybucji wpływają na zmiany w logistyce zwrotów. Z roku na rok zwiększa się liczba zakupów dokonywanych przez internet. Jest to główny powód wzrostu znaczenia i problemów logistyki zwrotów w przedsiębiorstwie. W niniejszym opracowaniu przybliżona została tematyka logistyki zwrotów w kontekście przepływu zwrotnego łańcuchów dostaw. Ponadto wskazano zależności i różnice pomiędzy podejściem procesowym a procesami logistycznymi. Głównym celem artykułu było jednak opracowanie etapów postępowania i scharakteryzowanie

24 Szerzej: K. Huk, J. Robaszkiewicz-Ostręga, Logistyka zwrotów... 
działań dotyczących tworzenia map procesów dla logistyki zwrotów. Usprawniają one procesy związane z przyjmowaniem i rozpatrywaniem zwrotów od klientów. Ważne jest ich precyzyjne stworzenie i implementacja, a także ciągłe monitorowanie i doskonalenie. Kadry zarządzające powinny mieć świadomość, iż stworzone procesy muszą elastycznie dostosowywać się do zmieniających się warunków. Niemniej jednak pozwalają one na określenie konkretnych działań i odpowiedzialności za zadania poszczególnych działów, a nawet osób. Z uwagi na ograniczoność opracowania nie została w nim poruszona tematyka Business Process Management (BPM), stanowiącego ważny aspekt poruszanego zagadnienia, nie przedstawiono również przykładów studiów przypadku konkretnych rozwiązań. Będą one eksplorowane w kolejnych opracowaniach $\mathrm{z}$ tego zakresu.

Bibliografia

Abt S., Zarzq̨dzanie logistyczne w przedsiębiorstwie, Polskie Wydawnictwo Ekonomiczne, Warszawa 1998.

Bednarz K.K., Podejście procesowe w komunikacji wewnętrznej przedsiębiorstwa, [w:] S. Nowosielski (red.), Podejście procesowe w organizacjach, „Prace Naukowe Uniwersytetu Ekonomicznego we Wroctawiu" 2009, nr 52, s. 23-33.

Bernon M., Cullen J., Gorst J., Reverse logistics self assessment workbook, Department for Transport, Cranfield University, University of Sheffield, Sheffield 2008.

Carter C.R., Ellram L.M., Reverse logistics: A review of literature and framework for future investigation, „Journal of Business Logistics” 2002, no. 9(1), s. 85-102.

Coyle J., Bardi E., Langley C., Zarządzanie logistyczne, Polskie Wydawnictwo Ekonomiczne, Warszawa 2002.

Hugos M., Zarzq̨dzanie tańcuchem dostaw. Podstawy, One Press Exclusive, Gliwice 2011.

Huk K., Robaszkiewicz-Ostręga J., Logistyka zwrotów na przykładzie hurtowni farmaceutycznej Neuca-Logistyca Sp. z o.o., „Prace Naukowe Uniwersytetu Ekonomicznego we Wroctawiu” 2018, nr 505, s. 303-314.

Kondracki K., Komunikacja w organizacjach, http://www.qpracy.pl (dostęp: 10.02.2020).

Krawczyk S., Zarzq̨dzanie procesami logistycznymi, Polskie Wydawnictwo Ekonomiczne, Warszawa 2001.

Nowosielski S., Procesy i projekty logistyczne, Wydawnictwo Uniwersytetu Ekonomicznego we Wrocławiu, Wroctaw 2008.

Rogers D.S., Tibben-Lembke R.S., Going backwards: Reverse Logistics Trends and Practices, Reverse Logistics Executive Council, Pittsburgh 2002.

Rojek T., Koncepcja łańcucha wartości w zarządzaniu przedsiębiorstwem, „Zeszyty Naukowe Uniwersytetu Szczecińskiego. Finanse, Rynki Finansowe, Ubezpieczenia” 2014, nr 66, s. 813-822.

Sadowski A., Logistyka zwrotna, [w:] S. Kauf, E. Płaczek, A. Sadowski, J. Szołtysek, S. Twaróg, Vademecum logistyki, Wydawnictwo Difin, Warszawa 2016, s. 177-193.

Slone E.R., Leading a Supply Chain Turnaround, „Harvard Business Review” 2004, no. 10, s. $114-121$.

Szołtysek J., Ewolucja logistyki zwrotnej, „Logistyka” 2009, nr 5. 
Szołtysek J., Logistyka zwrotna, [w:] D. Kisperska-Moroń, S. Krzyżaniak (red.), Logistyka, Biblioteka Logistyka, Poznań 2009, s. 434-443.

Twaróg S., System logistyczny, [w:] S. Kauf, E. Płaczek, A. Sadowski, J. Szołtysek, S. Twaróg, Vademecum logistyki, Wydawnictwo Difin, Warszawa 2016, s. 26-35.

Witkowski J., Zarzq̨dzanie łańcuchem dostaw. Koncepcje, procedury, doświadczenia, Polskie Wydawnictwo Ekonomiczne, Warszawa 2010.

Witkowski K., Aspekt logistyki zwrotów i recyklingu tworzyw sztucznych, [w:] J. Witkowski, A. Skowrońska (red.), Ekonomiczne, społeczne i środowiskowe uwarunkowania logistyki, „Prace Naukowe Uniwersytetu Ekonomicznego we Wrocławiu" 2015, nr 383, s. 302-317.

\section{Streszczenie}

Zmiany zachodzące w gospodarce oraz regulacje prawne wpłynęły na rozwój logistyki zwrotów. Obecnie coraz więcej produktów jest zwracanych do odbiorcy. Świadomość klientów, ich rosnące wymagania, zakupy przez internet, a tym samym rozwój e-commerce, globalizacja - to tylko niektóre czynniki mające wpływ na rozwój logistyki zwrotów. Dla usprawnienia działań i dodatkowych procesów związanych wyłącznie z logistyką zwrotów niezwykle pomocne jest podejście procesowe, a dokładnie tworzenie map procesów, stanowiących instrukcje i wytyczne dla pracowników. Celem artykułu jest wskazanie zależności i etapów tworzenia map procesów w logistyce zwrotów. Opracowanie ma charakter teoretyczno-empiryczny i zostało oparte na analizie literatury oraz przeprowadzonych studiach przypadku.

Słowa kluczowe: logistyka zwrotów, logistyka zwrotna, podejście procesowe, mapowanie procesów

Return logistics and process approach - dependencies and stages of creation

\section{Abstract}

Changes taking place in the economy as well as legal regulations influenced the development of return logistics. Currently, more and more products are returned to the recipient. Customer awareness, their growing requirements, online shopping, and thus the development of e-commerce, globalization are just some of the factors affecting the development of return logistics. To streamline operations and additional processes related only to returns logistics, the process approach is particularly helpful, namely the creation of process maps, which are instructions and guidelines for employees. The purpose of the article is to indicate the dependencies and stages of creating the mapping process in return logistics. Article is a theoretical and empirical and is based on the analysis of literature and conducted case studies.

Keywords: return logistics, reverse logistics, process approach, process mapping 